\title{
ON THE WAY TO AN ANTHROPARCHIC COMMUNITY OF LAW. THE EUROPEAN UNION AS THE SUBJECT OF GLOBAL LAW*
}

\section{Radosław Kołatek}

ABSTRACT: According to I. Pernice, the European Union has to be distinguished from an international organization for four reasons at least. ${ }^{1}$ First, there is no international organization where citizens have their own political representation and participate in the decision-making process. Second, direct legal action against individuals by directly applicable legislation does not happen. Third, the question of protection of fundamental rights against such 'international' power is not an issue. Last but not least, 'no international organization provides for legal remedies of individuals against measures of that organization since there is no action having direct effect to the individual'. Therefore the author believes that the EU is an organization of citizens albeit having an appearance of an organization between states. $^{2}$

Nevertheless one needs to remember that the European Union was founded as an intergovernmental organization by the European states on the principles of international law. That is why it has to be treated as a legal entity comprising the category of international organizations.

This project was funded with the support from the National Science Centre in Poland; decision number DEC-2013/08/M/HS5/00345.

1 I. Pernice, Multilevel Constitutionalism in the European Union, 'European Law Review' 2002, p. 517.

2 I. Pernice, ibid., at p. 518. 
Inasmuch as the role of individuals in the EU law-making process has been strengthened, their position was rather poor at the beginning of the European integration process. A direct right for individuals to submit a proposal for a legal act to the Commission is a great novelty not seen until now. Strengthening methods of democratic law-making by involving the European Parliament as well as national assemblies in the ordinary legislative procedure is again a fresh start. It is much the same with the system of judicial remedies differentiating the EU legal order from the horizontality of classical public international law.

International law as a source of legitimacy for the European Union has always been and is still valid. Nonetheless the history of EU integration demonstrates the continuous evolution of that legal system. Therefore it is increasingly more difficult for lawyers to describe precisely what type of international organization and juridical entity this phenomenon is. It is all the more intricate while seeking a definition in the world of classical international law.

An unravelling comes with Rafael Domingo's theory as the European Union fulfils Domingo's conditions to become an anthroparchic community of law. It happens through its legal order and participation of non-state actors in the law-making process. In such a case one can believe this juridical entity is also a subject in global law.

European integration in the perspective of international law has been being widely analysed so one can easily find some critical papers in this field. ${ }^{3}$ This subject has also been examined by political scientists. 'A sui generis political entity' as a term defining the European Union is well established in the theory of international relations. ${ }^{4}$ Les hommes politiques go even further in their descriptions naming the European Union an unidentified

3 M. Koskenniemi (ed.), International Law Aspects of the European Union, Kluwer Law International, The Hague 1998; J.H.H. Weiler (ed.), The EU, the WTO and the NAFTA: Towards a Common Law of International Trade?, OUP, Oxford 2001; J. Wouters, A. Nollkaemper, E. de Wet (eds), The Europeanisation of International Law: the Status of International Law in the EU and its Member States, TMC Asser Pres, The Hague 2008; E. Cannizzaro (ed.), International Law as Law of the European Union, Martinus Nijhoff, Leiden 2012.

4 E. Carmel, A. Cerami, T. Papadopoulos, Migration and Welfare in the New Europe: Social Protection and the Challenges of Integration, Policy Press, Bristol, 2012, at p. 75. 
political object $(\mathrm{UPO})^{5}$ or the first non-imperial empire. ${ }^{6}$ Regrettably these terms cause more confusion than explanation.

Despite the fact how descriptions assigned to the European Union are creative and diverse, agreement on what is the actual shape that the $\mathrm{EU}$ is taking is by no means easy. The size and functioning of the EU has been shaped and reshaped over the course of history. However the goal of an emerging 'ever closer union' is still in search of the paths of real and not ideal accomplishment. ${ }^{7}$ In fact, most institutional innovations bear some relation to past experience and borrow from it.

\section{The Crisis of International Law. On the Way to the New Global Law Theory}

It is actually intriguing to analyse the European Union in the perspective of a supranational order presented by Rafael Domingo in his monograph 'The New Global Law'. However before we do this it is necessary to detect the relation between international law and the global law as understood by the Spanish author.

He assumes that the negative phenomena of our times, including economic crises, crimes against humanity, the permanent deficit of democracy in international institutions are an incentive to create a new legal system ('New Global Law'). Its function would include reorganization of the world community ('humanity'), corresponding to new global societal needs and changes in consciousness.

He believes that global law would be a world legal order governing 'the ambit of justice as it affects humanity as a whole'. It is compatible with existing legal systems and traditions within the framework of international

5 J. Delors's speech at the first Intergovernmental Conference (IGC) to be held in Luxembourg, 9.9.1985; available at http://www.cvce.eu/content/publication/2001/10/19/423d6913-b4e2-4395-9157-fe70b3ca8521/publishable_en.pdf (28.5.2017).

6 J. M. Barroso's interview on 10.7.2007: https://www.youtube.com/watch?v=I8M1T-GgRU (28.5.2017).

7 G. Majone, TheMonetary Union and the Politicization of Europe, Keynote speech at the Euroacademia International Conference: 'The European Union and the Politicization of Europe', Vienna, 8-10.12.2011; http://euroacademia.eu/conference/the-european-union-and-the-politicization-of-europe/ (28.5.2017).

8 R. Domingo, The New Global Law, CUP, Cambridge 2011. 
economics and politics. Not only does it abandon steadily the corset of nation-states but also applies 'a legal metalanguage in response to the new challenges of globalization in all arrangements'. However one should retain that global law cannot be understood as a closed juridical system with a setup of rules binding its subjects. Domingo describes it as 'a system of systems, a iuris ordorum ordo, which necessarily would develop into an ordo orbis as it is gradually accepted by all communities and citizens of the world'. ${ }^{9}$

The traditionally understood concept of international law is the subject of Domingo's critical reflection. There is no other central argument in his work than that of the structural inadequacy of international law which is not sufficient to confront current dilemmas of globalization. He believes that no longer could the international law provide a fair explanation of the globalization phenomenon. 'The conceptual crisis of international law results from its pretension to deal with globalization without undergoing a change in its basic principles - principles founded upon an obsolete structure and doctrine, unacceptable for a society called to reflect true universality and solidarity.' ${ }^{10}$

Nevertheless just a simple change of paradigm run by international law scholars will not be of great help. With the fundamental transformation of our international reality which also includes the establishment of humanitas - mankind understood as community, one has to adopt a new apparatus. It is necessary to make the description of the change accurate. ${ }^{11}$ By creating a global community based on the common good we are in a position to observe the development of a new area of law referring to the international level - global law. As a result it needs a methodical analysis and description of sources of law as well as issues of law-making, legal compliance and interpretation.

The primary source of the current crisis of international law is situated in the untenable reduction of subjects of international law. It concerns a predominant position of sovereign states in the international legal order. This position is a result of acknowledging state as the only and at the same time privileged participant. All this leads to conferring a decisive position sovereignty (and particularly territoriality).

9 Ibid., at p. xvii.

$10 \quad$ Ibid., at p. 56.

11 Ibid., at pp. 115-117. 
The key difference between international law and global law lies in the legitimacy. The classical international paradigm is based on the idea of national sovereignty whereas global law is based on the inherent dignity of the human person (ius ex persona oritur). It is the human person who is the starting point and not the norms. ${ }^{12}$ The global law paradigm considers the person, not only in and of itself, nor as a member of a specific political community, but instead as the integral constituent part of humanity as a whole. In the statist international paradigm, the state takes the place of the person, whereas in this new global paradigm, the global community (that is to say, humanity) neither replaces, nor displaces, the person, but naturally integrates it therein. ${ }^{13}$

This new paradigm of the inherent dignity of the human person is the centre of the Domingo concept. Coinciding non-state actors such as multinational corporations, non-governmental organizations, informal associations of national authorities operating at the supranational level, create binding standards or actually influence national legislation, including the determination of the legal status of individuals. ${ }^{14}$

\section{The European Union - from the community of states}

Despite the fact that for Domingo the European Union is not in the main line of analysis, the Spanish author defines it as a juridical entity in statu nascendi. He believes it 'is indebted to the principle of a common unified law that for centuries accomplished the daunting task of unifying Europe while ensuring that individual sovereigns comprising the union retained their cultural and political identities. ${ }^{15}$ He also advocates that every legal order should recognize and protect the dignity of the person. ${ }^{16}$ Actually this demand has been fulfilled in the Charter of Fundamental Rights of the EU as article 1 constitutes that human dignity is inviolable. Therefore it must be respected and protected. This is an outcome of the long process to elevate the position of European citizens.

Obviously the role and the key position of the member states in the European integration process cannot be omitted. The European Union was

\footnotetext{
12 Ibid., at p. 101.

13 Ibid., at p. 187.

14 Ibid., at p. xvii.

15 Ibid., at pp. xix-xx.

16 Ibid., at p. 134.
} 
founded as an intergovernmental organization by European states on the principles of international law. As before, member states are still the most important actors of the EU legal system. However with the factors indicated in point 1 , one can consider whether the European Union is a legal entity falling into the category of organizations of the global juridical system.

One cannot forget that systematically the role of individuals in the EU law-making process was strengthened and the number of subjects participating in European integration increased (institutions, regions, interest groups). Moreover the system of judicial remedies differentiates the EU legal order from the horizontality of classical public international law. Direct effect operates not only in creating enforceable legal obligations between Member States and individuals, but also among individuals inter $s e .{ }^{17}$ In addition to the rights they already have to influence the EU decision-making process, individuals have a direct right to bring a so-called citizens' initiative to submit a proposal of a legal act to the Commission. ${ }^{18}$

Moreover the inclusion of new actors into the EU institutional setup has resulted in weakening the position of Member States. It also strengthened methods of democratic law-making by involving the European Parliament and introducing a scrutiny mechanism for national parliaments into the ordinary legislative procedure. Adopting the Charter of Fundamental Rights as a catalogue of universal values cannot be omitted; nor can the inclusion of EU citizens into the law-making process through the European Citizens' Initiative. In general terms it is comparable to the right of initiative of the European Parliament and the Council.

All the above justifies the examination of whether the European Union fulfils Domingo's conditions to become an anthroparchic community of law through its legal order and participation of non-state actors in the law-making process. If the answer is positive, one can name it a subject of globallaw.

For further analysis an observation of two parallel processes in the history of European Union integration is essential: the juridification of the integration of the European Union and its politicization. Both existed in the early stages of the establishment of the Community and both are critical from the perspective of an individual whose life is increasingly more often affected by EU law.

17 J.H.H. Weiler, The Constitution of Europe, CUP, Cambridge 1999, at p. 19.

18 Regulation (EU) no. 211/2011 of the European Parliament and of the Council of 16.2.2011 on the citizens' initiative, O.J. 11.3.2011, L 65, p.1. 


\section{Juridification of the EU integration}

One of the earliest studies on juridification dated 1987 is focused on social trends and relations with the law regulating an increasing amount of activities that may not have been legally established before. ${ }^{19}$ The only aspect of that process is a tendency for constant increase in formal, positive law. ${ }^{20} \mathrm{~A}$ more complex and more general definition describes it as a hallmark of constitutional democracy and the triumph of the rule of law over despotism. It is a process by which conflicts are increasingly solved by reference to the law, or when people increasingly think of themselves as legal subjects. ${ }^{21}$ However, the key issue is the construction and the expansion of judicial power in comparison to legislative power especially. ${ }^{22}$ In normative terms juridification refers to 'reliance on legal process and legal arguments, using legal language substituting or replacing ordinary politics with judicial decisions and legal formality. ${ }^{23}$

In the perspective of EU integration one can depict juridification as a widely capacious concept 'for references of increasing influence of the law, legalistic rules and the legalistic power of courts and judges on society in general and politics in particular'. The growing authority of courts and judges on the making of public policies at the expense of the legislative and executive institutions is only one dimension of this definition. The other is focused on 'the process by which quasi-judicial rules and procedures increasingly dominate the negotiations or decision-making in society'. ${ }^{24}$

The crucial role in the process of juridification in the EU has been reserved for the Court of Justice of the European Union (CJEU) as a result

19 G. Teubner, Juridification. Concepts, Aspects, Limits, Solutions [in:] G. Teubner (ed.), 'Juridification of Social Spheres: A Comparative Analysis in the Areas of labour, corporate, antitrust, and social welfare law', Berlin-New York ; 1987 EUI; series A, Law - 6, at pp. 3-48.

20 J. Habermas, The Theory of Communicative Action, Beacon Press, Boston 1987, vol. 2, at p. 359.

21 L. Ch. Blichner, A. Molander, Mapping Juridification, 'European Law Journal' 2008, no. 1 , at pp. 36-54.

22 K. Alter, Establishing the Supremacy of European Law: The Making of an International Rule of Law in Europe, OUP, Oxford 2003, at pp. 182-202.

${ }^{23}$ http://www.eurofound.europa.eu/emire/UNITED\%20KINGDOM/ JURIDIFICATION-EN.htm (23.10.2014)

24 Ch. Maas, An introduction to 'juridification' [in:] Ch. Maas (ed.), 'Juridification in Europe. The balance of powers under pressure?' Oranje, The Hague 2012, at pp. 4-5. 
of its unique design. Non-state actors (the Commission, private actors) 'were authorized to initiate suits' as well as persuade the CJEU to challenge the policies of European states. However, for the latter an opt-out from the Court's authority was prohibited. Therefore, national judiciaries in all member states have found ways to accommodate the supremacy of European law. ${ }^{25}$

Together, they thus combined to make EU law a 'new legal order of international law'. Due to its supranational character EU law became different from national or international law as well as developing into an effective legal order that had to be observed. 'EU law was accordingly seen to leave behind the purgatory of an uncertain status inhabited by the classical public international law and move up on the 'legal-quality continuum' between national law and international law'. ${ }^{26}$ However this did not happen painlessly.

Due to the fact that the CJEU supremacy doctrine was more threatening to institutional independence and authority to the highest national tribunals they argued strongly to reject it. However, there was a choice for the lower courts as they could circumvent doctrinal obstacles created by higher courts by appealing to the Court of Justice. They could also simply not consult the CJEU, which they were not legally required to do so but only encouraged according to article 267 TFUE. ${ }^{27}$ Circumventing national legal barriers through the use of EU law was also accessible to national courts of appeal. ${ }^{28}$

The CJEU established a relationship between EU law and Member States laws by a series of landmark rulings in the 1960s and early 1970s. This interconnection between national and supranational systems is defined by four doctrines of which the doctrine of direct effect is essential

25 K. Alter, The European Court's Political Power Across Time And Space, Faculty Working Papers 2009, no. 175, at p. 2; http://scholarlycommons.law.northwestern.edu/facultyworkingpapers/175 (28.5.2017).

${ }_{26}$ M. Accetto, The influence of EU law on national legal systems [in:] Ch. Maas (ed.), 'Juridification in Europe. The balance of powers under pressure?' Oranje, The Hague, 2012, p. 83.

27 According to article 267 TFUE when a question concerning the interpretation of the Treaty is raised before a national court, this court may suspend the national proceedings and request a preliminary ruling from the CJEU on the correct interpretation of the Treaty.

${ }^{28}$ K. Alter, The European Court's Political Power, OUP, Oxford 2009, at pp. 99-100. 
for constituting the European community of law. ${ }^{29}$ The other one with a similar impact on this relationship is the judicial review with the system of judicial remedies and enforcement. ${ }^{30}$ Both of these have also had an impact on the increasing role of individuals in the EU.

As B. Vesterdorf, the President of the General Court, put it in 2003: 'The Court of Justice's judicial activity has been of the most fundamental importance to the development of the Communities. It is its case law which has ensured that in the Communities, now the European Union, the full rigours of rule of law have been established at a Community level, as have a number of principles of fundamental importance to the citizen whilst a high degree of unity and coherence in the interpretation and application of Community law throughout the European Union has, for the most part, been assured'. ${ }^{31}$

\subsection{Direct effect}

Introduced in 1963 the judicial doctrine of direct effect provides the presumption that the legal norms of the EU, being clear, precise and self-sufficient, must be regarded as the law of the land in the sphere of application of EU law. This operates not only in creating enforceable legal obligations between Member States and individuals, but also among individuals inter $s^{32}$ So the latter may invoke the norms of the European Union before their national courts. ${ }^{33}$ The repercussions were of momentous character as this brought individuals into the EU legal order.

29 T. Hartley, The Foundations of European Community Law, OUP, Oxford, 2003, at pp. 197-202.

30 J. H. H. Weiler, op. cit., at pp. 19-31.

31 B. Vesterdorf, The Community Court System Ten Years from Now and Beyond: Challenges and Possibilities, 'European Law Review' 2003, no. 3, at p. 309.

32 N. V. Algemene Transport- en Expeditie Onderneming Van Gend \& Loos v. Nederlandse administratie der belastingen (Netherlands Inland Revenue Administration), Case 26/62, Judgement of 5.2.1963, ECR at p. 13: 'this Treaty is more than an agreement which merely creates mutual obligations between the contracting states. This view is confirmed by the preamble to the Treaty which refers not only to governments but to peoples'; 'the Community constitutes a new legal order of international law for the benefit of which the states have limited their sovereign rights, albeit within limited fields, and the subjects of which comprise not only Member States but also their nationals'.

33 P. Craig, G. de Burca, EU Law: Text, Cases and Materials, OUP, Oxford 2011, at p. 181. 
By the judicial doctrine of direct effect the CJEU 'reversed the normal presumption of the public international law whereby international legal obligations are result-oriented and addressed to states'. According to the norms of international law when the aim of international obligation (e.g. trade agreement) is to confer rights or duties on individuals within the state, an individual cannot invoke them before national tribunals without providing such a remedy by internal constitutional or statutory law. However direct effect means that a Member State, while violating its duties of EU law, cannot bring the dispute to a intergovernmental level. If a Member State had sought to do so, it would have been faced with legal action taken by individuals before its own courts. ${ }^{34}$

One can assume that the aim of the eminent language of the Van Gend en Loos ruling, in which the Court regarded the Union not only as an instrument binding among states but also concerning the peoples of those states, was intended to legitimize the conclusion that the Treaty was unlike other international agreements due to the possibility for individuals to derive their rights from it. ${ }^{35}$ Therefore individuals too, and not only Member States, must be 'visualized' as being subjects of the law of the European Union. As a consequence of the democratic ideal, the European Union calls for the participation of everybody resulting not only in the liability of natural persons but also in legal protection of their prerogatives. ${ }^{36}$

In this way, the CJEU transformed the Treaty 'from a classical instrument of international law into (or towards) the constitution of a quasi-federal organism' as F. Jacobs put it. ${ }^{37}$

\subsection{Judicial review}

With an increase in the EU powers to the extent where in many areas it is the EU rather than the nation state that adopts the relevant law, the legal system of the European Union provides for an adequate system of legal remedies. The latter do not exist only for the benefit of Member States

34 J.H.H. Weiler, op. cit., at pp. 19-20.

35 P. Craig, G. de Burca, op. cit., at p. 185.

36 P. Pescatore, The Doctrine of 'Direct Effect': An Infant Disease of the Community Law, 'European Law Review' 1983, no. 8, at p. 158.

37 F. Jacobs, The Evolution of the European Legal Order, 'Common Market Law Review' 2004, vol. 41, no. 2, at pp. 307-308. 
having considerable political influence on EU decision making to defend their interest. More importantly legal remedies serve the individual who is affected by EU law.

Even when EU law is not transposed into national legal systems and EU law triumphs in cases of conflict between national and EU law, it often transpires that individuals are affected directly. Through majority voting, EU legal acts have created obligations for national governments even when they have not agreed to them. Such activities - those that bind states thus affecting private actors only indirectly and those that affect individuals directly - are indications of authority'. ${ }^{38}$

By creating a system of judicial review, the founding Treaty intended to embrace the widest possible range of EU measures and to ensure that no legal act escaped the possibility of the Court's assessment. ${ }^{39}$ What is typical for a non-unitary legal system like the one in the European Union is the hierarchy of norms within it. So the organization of judicial review operates on two levels. One can name two sets of legislative acts and administrative measures are subjects to judicial review. The first consists of those measures the EU adopts by itself. Those reviewable for conformity with Treaties are acts of the Parliament, the Council, the Commission. The other group is legislation of acts of Member States which are reviewable for conformity with EU law including secondary legislation. This is what 'differentiates the EU legal order from the horizontality of classical public international law. ${ }^{40}$

In accordance with articles 258-262 TFUE the Commission or an individual Member State may bring an action against a Member State for failure to fulfil its obligations under the Treaty. In this way the EU legal system drives the Commission as a supranational body in the exceptional role which invokes the compulsory jurisdiction of the Court of Justice against a defaulting Member State. It opposes the traditional international law concept where the enforcement of the treaty obligations is a matter to be settled amongst the contracting parties themselves.

With the Lisbon Treaty, jurisdiction of the CJEU in annulment actions has been extended as acts of the European Council and EU bodies,

38 R.D. Kelemen, The political foundations of judicial independence in the European Union [in:] S. K. Schmidt, R.D. Kelemen (eds), 'The Power of the European Court of Justice' Routledge, New York 2014, at pp. 43-58.

39 P. Craig, G. de Burca, op. cit., at p. 485.

40 J.H.H. Weiler, op. cit., at p. 26. 
offices and agencies, intending to produce legal effects vis-à-vis third parties became included (article 263, 1st par. TFUE). It was a result of widespread use of the delegation of powers to various EU agencies and bodies in the last decades. A considerable number of legal acts issued by the above bodies directly affecting natural and legal persons in the end caused the inclusion of acts of the above bodies to the scope of judicial review. ${ }^{41}$

While national governments appeared to be willing to ignore the CJEU jurisprudence, ignoring their own courts was a different matter entirely. Remedy for imperfection of articles 258-262 TFUE became judicial review within the judicial systems of the Member States in collaboration with the CJEU.

According to article 267 TFUE when a question concerning the interpretation of the Treaty is raised before a national court, this court may suspend the national proceedings and request a preliminary ruling from the CJEU on the correct interpretation of the Treaty. So the uniform interpretation of EU law throughout Member States became ensured by this article. As a result Member State courts and lower courts in particular have become empowered judicially. Furthermore national court rulings created a negative consequence for governments for violating EU law because in a rule-of-law society, governments follow their courts regardless of whether European or national law is at stake. ${ }^{42}$

Establishing doctrines of direct effect and supremacy the Court of Justice of the European Union formed the foundations of a European legal order. With an increase in the authority of the EU legal system, private litigants raised more suits and the national courts referred more cases. The Commission also became more 'willing to use infringement suits to promote compliance and to help advance the agenda of European integration'. ${ }^{43}$

\section{Politicization of the EU integration}

The act of shifting an issue into the field of politics which makes previously apolitical matters political or the demand for it is the core of politicization. It is a process 'by means of which decision-making powers and the associated authoritative interpretations of facts and circumstances

41 M. Busuioc, European Agencies: Law And Practices of Accountability, OUP, Oxford 2013, at pp. 39-41.

42 K. Alter, op. cit., at p. 220.

43 Ibid., at p. 217. 
are brought into the political sphere'. Nevertheless making a topic a subject of public discussion as well as public regulation belongs to the attributes of politicization too. The normative framework of the institutional order is itself subject to political criteria when the entire decision-making entity is politicized and not only a decision itself. Regarding the subjects or the agents of politicization one can name the individuals or groups who participate in the political process. Among the latter one can find politicians, experts, interest groups, mass media and those in a position to organize political protest. ${ }^{44}$

What determines the processes of the politicization of the European Union is not only growing political authority indicated by the transformation from a traditional international organization to a more encompassing 'political system' but also the increasing involvement of the wider public in EU institutional reform and policy issues. ${ }^{45}$ This participation means 'an increase in polarization of opinions, interests or values and the extent to which they are publicly advanced towards policy formulation within the EU'. There are three indicators: rising awareness, mobilization and polarization by which the process of politicization is observed. ${ }^{46}$

The increasing influence of EU institutions attracts more public attention provoking utilization and support for the integration on the one side as well as counter reactions to the EU policies on the other. Due to this increase non-state actors (societal groups, individuals) resolve to achieve desired goals through EU institutions. That fact is another vital feature of the EU's politicization. By the inclusion of non-state actors in the decision-making process the position of the Member States as parties of the Treaties diminished. ${ }^{47}$

Discussing the process of politicization of the European Union one should point out three features:

1) inclusion of interest groups and civil society organizations in the EU decision-making process;

44 P. de Wilde, M. Zürn, Can the Politicization of European Integration be Reversed, 'Journal of Common Market Studies' 2012, vol. 50, at pp. 141-142.

45 S. Hix, The Political System of the European Union, Palgrave Macmillan, New York 2005, at pp. 86-89.

46 P. de Wilde, No Polity for Old Politics? A Framework for Analyzing Politicization of European Integration, 'Journal of European Integration' 2011, no. 5, at pp. 566-567.

47 P. de Wilde, M. Zürn, op. cit., at p. 140. 
2) the increasing role of the European Parliament and the scrutiny mechanism for national parliaments in the EU decision-making process;

3) the increase in the citizens' position in the EU decision-making process.

\subsection{Interest groups and civil society organizations as non-state actors}

\subsubsection{Increasing role of interest groups and civil society organizations in the EU}

The EU decision-making process exhibits a regularized system of relations between EU institutions and interest groups. The development of the single market and monetary integration are not limited to the most visible EU institutions like the Parliament or the Commission. The manifold regulatory committees whose main task it is to deepen and smooth economic integration should also be taken into account. To some extent the emergence of these nodes of European statehood have triggered the development of European civil society networks and groups of interest. However, for a long time European civil society was highly selective in terms of the representation of different kinds of social forces being limited to specific networks broadly controlled by business associations. ${ }^{48}$

Over the years groups representing individuals have become essential actors in the social field tackling poverty and social exclusion at the most. Being engaged in dialogue with public authorities they assisted in the implementation of EU initiatives and policies in the EU countries. As a result an intensification in the cooperation between the Commission and NGOs has covered a wide range of issues, from policy dialogue to project and programme management, both within the EU and in its partner countries. The more responsibilities the Commission acquired regarding new policy areas, the higher the number of NGOs operating within the EU.

48 H-J. Bieling, European globalization and world order politics [in:] P. Nousios, H. Overbeek, A. Tsolakis, 'Globalisation and European Integration', Routledge, London, New York 2012, at p. 181. 
This can be observed by the increasing number of national NGOs creating or joining European associations and networks often based in Brussels. ${ }^{49}$

The most European of interest organizations are associations created at the supranational level. Business groups were the earliest to recognize the benefits of participating in the law-making process on an EU level in the early years of EU integration. A well-known organization representing farmers and agricultural cooperatives before EU institutions is COPACOGECA established at the end of the 1950s. ${ }^{50}$ Those interest groups were followed quickly by their opponents: the trade-unions.

\subsubsection{Institutionalizing cooperation between interest groups, NGOs and the Commission}

Some institutions of the European Union like the European Parliament, the Economic and Social Committee and the Committee of the Regions have a strong tradition of close contacts with NGOs and interest groups. At the beginning of the ' 90 s wide consultation on the communication gap between the EU and its citizens was undertaken by the Commission. Explicit rules such as accreditation, registration, code of conduct towards special groups did not exist before that. As a result the Communication from the Commission: 'An Open and Structured Dialogue between the Commission and Interest Groups' was published in $1992 .{ }^{51} \mathrm{It}$ was adopted to improve the quality of EU policies and legislative proposals.

As the next step, the Commission approved a discussion paper 'The Commission And Non-Governmental Organizations: Building A Stronger Partnership' in 2000. The aim was to provide an overview of the existing relationships between the Commission and NGOs and suggest possible ways to develop these contacts by considering the measures needed to improve those relations including EU funding for NGO-managed activities. ${ }^{52}$

49 Commission discussion paper The Commission and non-governmental organisations: building a stronger partnership, COM(2000)11 final.

50 Official website of COPA-COGECA: www.copa-cogeca.be (24.1.2015).

51 Communication from the Commission, An Open and Structured Dialog between the Commission and Interest Groups, SEC/92/2272 final, OJ 5.3.1993, C 63, at pp. 2-7.

52 The Commission Discussion Paper, The Commission And Non-Governmental Organisations: Building A Stronger Partnership: http://ec.europa.eu/transparency/ civil_society/ngo/docs/communication_en.pdf. 
The Commission's White Paper on Governance published in 2001 emphasized the necessity for active communication regarding EU issues among institutions of the European Union and the general public. Especially - according to the Commission - civil society should be involved as it 'offers a real potential to broaden the debate on Europe's role. It is a chance to get citizens more actively involved in achieving the Union's objectives and to offer them structured channel for feedback, criticism and protest'. ${ }^{53}$

In December 2002, ten years after publishing the first document on bridging the gap between interest groups and EU institutions, a new Communication was adopted by the Commission. 'General principles and minimum standards for consultation of interested parties' set up a coherent and flexible framework for consultation of stakeholders, including NGOs. ${ }^{54}$ The Commission has recognized that the more institutionalized the consultation with interest groups becomes, so the risks of political disasters are reduced. By collective decision-making at the very early stage the Commission can avoid or lower the risks of opposition among the potential stakeholders. ${ }^{55}$ It is also highly convenient, from the perspective of the facilitation of transnational exchange, to have interest groups included in this process as sources of information, support and legitimacy.

In order to get a better view of the interest groups that work to influence EU policy making the European Parliament and the European Commission set up the Transparency register in 2011. It operates on the basis of an Inter-institutional Agreement (IIA) between the European Parliament and the European Commission. ${ }^{56}$ It is part of the policy of openness about relations with organizations and self-employed individuals engaged in EU policy-making and policy implementation. Organizations and companies that want to contribute to the policy process are requested to sign up to this voluntary register and provide specific information about

53 Communication from the Commission, European Governance - A White Paper, $\operatorname{COM}(2001) 428$ final; O.J. 12.10.2001, C-287, p. 1.

54 Communication from the Commission, 'Towards a reinforced culture of consultation and dialogue - General principles and minimum standards for consultation of interested parties by the Commission', COM(2002) 704 final, not published in the Official Journal.

55 S. Mazey, J. Richardson, Commission-Interest Group Relations [in:] A. Stone Sweet, W. Sandholtz, N. Fligstein (eds), 'The Institutionalization of Europe' OUP, Oxford 2001, at p. 72 .

56 Agreement between the European Parliament and the European Commission on the establishment of a transparency register for organisations and self-employed individuals engaged in EU policymaking and policy implementation. OJ 22.7.2011, L-191, at p. 29. 
them: objectives, members, sources of funding and expenditure. By providing a single code of conduct the register guarantees that organizations and self-employed individuals 'play by the rules' in full respect of ethical principles. The enforcement of those rules is ensured by the mechanism of complaints and sanctions against those breaching the code. ${ }^{57}$

The Transparency register is also a useful instrument for citizens wishing 'a direct and single access to information about who is engaged in activities aiming at influencing the EU decision making process, which interests are being pursued and what level of resources are invested in these activities'. ${ }^{58}$

\subsubsection{Role of consultation between the Commission and interest groups and NGOs in the EU's decision-making process}

Participation in the processes of consultation is also essential for interest groups as it widens their scope of knowledge as well as allowing them to influence the process of law-making. However the Commission does not differentiate between civil society organizations and other forms of interest groups in its policy of consultation. Those consulted are 'interested parties' meaning all those who wish to participate in consultations run by the Commission. The negative side of the institutionalized consultation process with 'interested parties' has an effect often on the national level. Some non-state actors, not being engaged in transnational exchange, are able to go to EU institutions with the purpose of destabilizing national laws or procedures which they dislike. ${ }^{59}$

Although there is no great specificity of consultation rules in the Commission one can name four stages of this process. It is a general scheme and this neat pattern is not always followed. The key issue is the so-called stakeholder dialogue taking place in the different frameworks depending on the subject being taken into account. For example, the European Platform against Poverty and Social Inclusion is vital for bringing together

57 Information from the website of Transparency Register run by the European Parliament and the Commission jointly: http://ec.europa.eu/transparencyregister/info/ homePage.do?redir=false\&locale=en (21.1.2015).

58 Information from the website of the Commission: http://ec.europa.eu/transparencyregister/info/homePage.do?redir=false\&locale=en (21.1.2015).

59 S. Mazey, J. Richardson, op. cit., at p. 74. 
EU-level NGOs and social partners in the fields of employment, social affairs and inclusion as well as representatives of EU Institutions and other international organizations, representatives of national, regional and local authorities, think-tanks and foundations for issues relating to social inclusion. ${ }^{60}$

The dialogue or debate is initiated in the first stage being called a wake-up call for stakeholders. Usually the publication of a Green Paper or a communication from the Commission begins that phase. The second stage is the time for mapping opinions and interests. At this stage it is decided who matters. Typically 'this involves bringing together many stakeholders in a forum or conference'. It is very often that public consultations with citizens and stakeholders are taken through the official website or by circulating a questionnaire among interested stakeholders. At the third stage (insider processing) a smaller group advisory committee or high-level group in charge of the detailed processing of issues is created. In this case social dialogue refers to discussions, consultations, negotiations and joint actions involving some organizations e.g. representing the two sides of industry (employers and workers). The fourth stage involves formal proposals. Then a new policy cycle starts and the Commission continues close dialogue with the key stakeholders as the inter-institutional battle develops. ${ }^{61}$

For a better interaction between the EU institutions and Europeanlevel organizations and networks the European Economic and Social Committee (EESC) set up a Liaison Group in February 2004. The main task for the Group is monitoring joint initiatives and ensuring that the EESC has a coordinated approach towards the networks. ${ }^{62}$ One of them is Social Economy Europe (SEE) - the platform working on increasing the involvement of social economy in EU economic and social policies and programmes. ${ }^{63}$ Strengthening NGOs' voice vis-a-vis the EU was the purpose of establishing the EU Civil Society Contact Group (CSCG) as an informal network. Owing to this eight large NGO sectors - culture, environment,

60 Communication from the Commission 'The European Platform against Poverty and Social Exclusion: A European framework for social and territorial cohesion' SEC(2010) 1564 final.

61 S. Mazey, J. Richardson, op. cit., at p. 86.

62 Information from the website of the European Economic and Social Committee: http://www.eesc.europa.eu/?i=portal.en.liaison-group.

63 Information from the website of the SEE: http://www.socialeconomy.eu.org/?lang=en (28.1.2015). 
education, development, human rights, public health, social and women are brought together. ${ }^{64}$

Through the PROGRESS programme set up in 2007-2013, the Commission helped to increase the involvement of several European umbrella NGO networks in the following fields: ${ }^{65}$

- promoting social inclusion: Caritas Europa, the Confederation of family organizations (COFACE), International Street Workers Network (Dynamo), European Anti Poverty Network (EAPN), European Network for Social Integration Enterprises (ENSIE), European Social Network (ESN), Eurochild, Eurocities, Eurodiaconia, EuroHealthNet, the European Federation of national organizations working with the homeless (FEANTSA), Mental Health Europe (MHE), the Platform for International Cooperation on Undocumented Migrants (PICUM);

- promoting gender equality: European Women's Lobby;

- representing the rights of people exposed to discrimination: AGE Platform Europe, European Disability Forum (EDF), European Network Against Racism (ENAR), International Lesbian and Gay Association - Europe (ILGA Europe), European Roma Information Office (ERIO).

\subsection{Increasing role of the European Parliament and national parliaments in the $\mathrm{EU}$ decision-making process}

\subsubsection{The role of the European Parliament}

According to article 14(2) TEU the European Parliament is composed of representatives of EU citizens elected for a period of five years. It is the only European Union institution where all EU citizens elect members of

64 Information from the website of the EU Civil Society Contact Group (CSCG): http://www.act4europe.org/code/en/default.asp (1.2.2015).

65 The PROGRESS programme was a financial instrument in 2007-2013 supporting the development and coordination of EU policy in the five areas: employment, social inclusion and social protection, working conditions, anti-discrimination, gender equality; Community Programme For Employment And Social Solidarity (Progress) PROGRESS/003/2006; http://ec.europa.eu/social/BlobServlet?docId=1588\&langId=en (21.1.2015). 
that body by direct universal suffrage. As time passed, with every new treaty, 'the European Parliament's powers have been progressively and regularly increased'. It was 1979 when the first elections to the EP were handed over to European citizens. At that time the Parliament had a mere consultative role. However, its current responsibility in the co-decision procedure for most legislative acts is essential now. ${ }^{66}$

New supervisory powers for the EP were introduced by the Maastricht Treaty. It was a part of the citizenship package introduced with the belief that the Parliament might play a more distinctive role to make the EU more accountable to its citizens. ${ }^{67}$ Two measures of that package should be given special attention.

In the first case the European Parliament under article 226 TFEU is entitled to set up Committees of Enquiry to investigate 'alleged contraventions or maladministration in the implementation of Union law'. The second measure is a type of request. According to article 227 TFUE 'any natural or legal person residing or having its registered office in a Member State' is in possession of 'the right to address a petition to the European Parliament on a matter which comes within the Union's fields of activity and which affects him, her or it directly'.

Whether the increase in the European Parliament's powers will be taken into account by EU citizens remains to be seen when deciding on participation in the European elections or not in great numbers. The only difficulty is made by the fact that 'the European elections are often used as 'mock' elections indicating the popularity of the government before the 'real' elections which, in the minds of most electors, are and remain the national legislative and/or presidential ones. ${ }^{68}$

Nevertheless transferring more power to the European Parliament does not necessarily make the EU more democratic. One should remember that the constitutional order of the EU is different from that of the traditional member state. Therefore the pluralistic nature of the EU legal order which is based on its 'osmotic' relation with its member states has to be taken into account. 'In this regard, it is important to enhance democratic

66 J.-C. Piris, The Lisbon Treaty. A Legal and Political Analysis, CUP, Cambridge 2010, at pp. $114-115$.

67 S. Douglas-Scott, Constitutional Law of the European Union, Longman, Harlow 2002, at p. 94.

68 J.-C. Piris, op. cit., at p. 122. 
legitimacy at the level of national parliaments in the EU, by increasing their role. ${ }^{69}$

\subsubsection{The role of national parliaments}

Until 1979 the European Parliament consisted of national parliaments which were designated by the latter. General elections at the end of the 1980s broke this link with serious effects. It was believed that national assemblies had transferred part of their legislative power to their governments. The relocations of power were boosted with consecutive Treaties. 'This deprived national parliaments of direct powers on the adoption of legislative acts' in certain fields. ${ }^{70}$

The necessity to adapt to this new legal and political situation forced national assemblies to modify their procedures and establish fresh lines of cooperation with their governments. ${ }^{71}$ A subject of great importance for many Member States was amending national constitutions in a way which strengthened parliamentary control 'over the decisions made by the representatives of their governments in the EU Council'. ${ }^{72}$ Apart from that, all national parliaments established committees of EU Affairs. Establishing in 1989 the Conference of Community and European Affairs Committees of Parliaments of the EU (COSAC) was an element of building a network among the parliaments of the Member States. It became an instrument of influencing EU institutions on legislative proposals under preparation. ${ }^{73}$

The Laeken Declaration also draws the attention of the public opinion as well as officials in Europe to the questions on the role of national assemblies in the architecture of the European Union. ${ }^{74}$

Should they be represented in a new institution, alongside the Council and the European Parliament? Should they have a role in areas of European

69 S. Douglas-Scott, op. cit., at p. 538.

70 J.-C. Piris, op. cit., at pp. 122-123.

71 I. Pernice, The role of national parliaments in the European Union [in:] D. Melissas, I. Pernice (eds.), 'Perspectives of the Nice Treaty and the intergovernmental Conference in 2004' Nomos, Baden-Baden 2001, at p. 78.

72 J.-C. Piris, op. cit., at pp. 123-124.

73 Information from European Union Institutions, Bodies, Offices and Agencies European Parliament, Rules of Procedure of the Conference of Parliamentary Committees for Union Affairs of Parliaments of the European Union (2011/C 229/01), OJ 4.8.2011, C-229, at pp. 1-6.

74 Final Act of the Intergovernmental Conference, Declaration no. 23 on the future of the Union. 
action in which the European Parliament has no competence? Should they focus on the division of competence between Union and Member States, for example through preliminary checking of compliance with the principle of subsidiarity?

The Lisbon Treaty has answered, at least, some doubts and questions raised in the Laeken Declaration. Strengthening the position of national parliaments over their government's positions on EU matters by exercising deeper and tighter control over the executive was one issue. Beyond this, assemblies of the Member States could use the Treaty provisions 'to invest more time and resources' while working with EU matters. Owing to 'the direct and swift flow of information on EU issues' they would be able to participate in the European politics more than ever before. ${ }^{75}$

The new powers for national parliaments were conferred in article 12 TEU. One can list three essential rights brought by the Lisbon Treaty. A direct role in checking whether the EU institutions respect the principle of subsidiarity is the key issue. On the basis of article 8 of Protocol no. 2 on the application of the principle of subsidiarity, national parliaments are entitled entrée to the Court of Justice of the European Union. Besides this, national parliaments are entitled to obtain information directly from EU institutions as well as legislative proposals of the Union. This direct link between national assemblies and the institutions of the EU is a novelty in comparison to the earlier period. At that time any information was delivered via national governments according to 'the normal procedure in all 'classic' international organizations. ${ }^{76}$

Their role in participating 'in the evaluation mechanisms for the implementation of the Union policies in the Area of Freedom, Security and Justice and political monitoring of Europol and Eurojust is also of vital importance.

Ibid., at p. 127. 


\subsection{The increase in the citizens' position in the $\mathrm{EU}$ decision-making process}

\subsubsection{The citizens' status in the EU}

'In a democratic system, there cannot exist another basis for the legitimacy of public authority but the citizens, and this is what we find in the European Union' ${ }^{77}$ Individuals enjoy the liberties of the internal market and the rule of non-discrimination as citizens in whatever Member State they live or act. Equal rights and equal obligations in accordance with provisions of the Treaties and the European legislation is an indivisible part of the EU citizenship. They also hold voting rights for regional, national and European elections. To ensure that universal suffrage is given effect in each case the national administrations and courts are bound to it. ${ }^{78}$

An expression of the common legal status of EU citizens is stated in article 20 TFEU. It is the citizens of Member States who have given themselves this new citizenship. That is the source of legitimacy for all EU public authorities as the allocation of powers shared by national and European levels of government is continuously reorganized and re-shifted. Moreover it raises 'citizens' awareness upon the fact that European Union is as much their instrument of political action as are the Member States and their regions, and that the Union is not a foreign, nameless power. ${ }^{79}$

One cannot forget that the early treaties of the European Communities did not contain any reference to human rights or their protection. Nevertheless in the meantime the CJEU realized that a new approach on the protection of individuals is necessary as increasingly more cases came before the ECJ alleging human rights breaches occurring in areas within the scope of EU law. So as a result fundamental rights have been included in the 'general principles' of European Union law. ${ }^{80}$ Proclaiming the Charter of Fundamental Rights of the European Union in 2000 was the next step in the process of strengthening the position of citizens in the EU. But only

77 I. Pernice, Multilevel Constitutionalism in the European Union, 'European Law Review' 2002, at p. 514.

78 Ibid., at p. 515.

79 Ibid., at p. 515.

80 M. Dybowski, Prawa fundamentalne w orzecznictwie ETS [Fundamental Rights in the ECJ jurisprudence], C.H. Beck, Warszawa 2007, at p. 8-11. 
the Lisbon Treaty brought legal instruments in the format which is more democratic, more efficient and better understood by the citizens.

\subsubsection{The European Citizens' Initiative}

It is two years since the launch of the European Citizens' Initiative (ECI) which is the first tool for transnational participatory democracy - an instrument for citizens to call on the Commission to initiate legislation (article 11(4) TFEU). ${ }^{81}$ Never before could one million EU citizens residing in at least one quarter of Member States invite the Commission to submit a proposal for a legal act which they consider to be required in order to implement the Treaties. In this way the resolution of article 10.1 TEU that the principle governing the functioning of the EU 'shall be founded on representative democracy' has received its legal instrument.

The ECI is built on the logic of direct democratic involvement of citizens in the policy formulation phase of EU policy-making. It stands in the tradition of procedures to guarantee democratic input legitimacy. As a direct call for a specific EU legal instrument the ECI is ultimately addressed to the Commission, which alone among the institutions has the right to submit legislative proposals according to article 11(4) TEU. In this respect, the ECI is similar in nature to the right of initiative conferred on Parliament (article 225 TFEU) and on the Council (article 241 TFEU).

Between the entry into force of Regulation (EU) no 211/2011 on 1.4.2012 and 1.3.2014, 40 initiatives submitted an application for registration to the European Commission. 23 initiatives were accepted for registration by the Commission and started the signature gathering process. 'In respect of the 5.5 million signatures collected by the first 21 ECIs almost $90 \%$ of ECI signatures were collected by the three successful initiatives: One of Us (35\%), Right to Water (34\%) and Stop Vivisection (20\%). ${ }^{82}$

It is important for organizers to conduct a proactive policy vigorously when encouraging a civil society for any initiative. Otherwise citizens

81 Legal basis is set out in the Regulation (EU) no. 211/2011 of the European Parliament and of the Council of 16.2.2011 on the citizens' initiative, OJ L 65, 11.3.2011, at p.1.

82 C. Berg, J. Thomson, An ECI That Works! Learning from the first two years of the European Citizens' Initiative, The ECI Campaign, Olsdorf 2014, at p. 11: http://ecithatworks. org/wp-content/uploads/2014/04/An_ECI_That_Works.pdf. 
will not be informed properly. According to article 11(1-3) TEU to facilitate conducting the ECI the European institutions 'shall give citizens and representative associations the opportunity to make known and publicly exchange their views in all areas of Union action'. Maintaining an open, transparent and regular dialogue with representative associations and civil society is a must as well. One cannot forget that the Commission shall carry out broad consultations with parties concerned in order to ensure that the Union's actions are coherent and transparent.

\section{Bibliography}

1. Accetto M., The influence of EU law on national legal systems [in:] Ch. Maas (ed.), 'Juridification in Europe. The balance of powers under pressure?' Oranje, The Hague 2012.

2. Alter K., Establishing the Supremacy of European Law: The Making of an International Rule of Law in Europe, OUP, Oxford 2003.

3. Alter K., The European Court's Political Power Across Time And Space, Faculty Working Papers 2009, no. 175, http://scholarlycommons.law.northwestern. edu/facultyworkingpapers/175 (28.5.2017).

4. Alter K., The European Court's Political Power, OUP, Oxford 2009.

5. Bieling H-J., European globalization and world order politics [in:] P. Nousios, H. Overbeek, A. Tsolakis, 'Globalisation and European Integration', London, New York, Routledge 2012.

6. Berg C., Thomson J., An ECI That Works! Learning from the first two years of the European Citizens' Initiative, The ECI Campaign, Olsdorf 2014, http:// ecithatworks.org/wp-content/uploads/2014/04/An_ECI_That_Works.pdf.

7. Blichner L. Ch., Molander A., Mapping Juridification, 'European Law Journal' 2008, No. 1.

8. Busuioc M., European Agencies: Law And Practices of Accountability, OUP Oxford 2013.

9. Cannizzaro E. (ed.), International Law as Law of the European Union, Martinus Nijhoff, Leiden 2012.

10. Carmel E., Cerami A., Papadopoulos T., Migration and Welfare in the New Europe: Social Protection and the Challenges of Integration, Policy Press, Bristol 2012.

11. Craig P., de Burca G., EU Law: Text, Cases and Materials, OUP, Oxford 2011.

12. Domingo R.: The New Global Law, CUP, Cambridge 2011.

13. Douglas-Scott S., Constitutional Law of the European Union, Longman, Harlow 2002.

14. Dybowski M., Prawa fundamentalne w orzecznictwie ETS, C.H. Beck, Warszawa 2007. 
15. Habermas J., The Theory of Communicative Action, Beacon Press, Boston 1987.

16. Hartley T., The Foundations of European Community Law, OUP, Oxford 2003.

17. Hix S., The Political System of the European Union, Palgrave Macmillan, New York 2005.

18. Jacobs F., The Evolution of the European Legal Order, 'Common Market Law Review' 2004, vol. 41, no. 2.

19. Kelemen R.D., The political foundations of judicial independence in the European Union [in:] Schmidt S. K., Kelemen R.D. (eds.), 'The Power of the European Court of Justice', Routledge, New York 2014.

20. Koskenniemi M. (ed.), International Law Aspects of the European Union, Kluwer Law International, The Hague 1998.

21. Maas Ch., An introduction to 'juridification' [in:] Maas Ch. (ed.), 'Juridification in Europe. The balance of powers under pressure?', Oranje, The Hague 2012.

22. Mazey S., Richardson J., Commission-Interest Group Relations [in:] A. Stone Sweet, W. Sandholtz, N. Fligstein (eds), 'The Institutionalization of Europe', OUP, Oxford 2001.

23. Pernice I., Multilevel Constitutionalism in the European Union, 'European Law Review' 2002.

24. Pernice I.: The role of national parliaments in the European Union [in:] D. Melissas, I. Pernice (eds.) 'Perspectives of the Nice Treaty and the intergovernmental Conference in 2004', Nomos, Baden-Baden 2001.

25. Pescatore P., The Doctrine of 'Direct Effect': An Infant Disease of the Community Law, 'European Law Review' 1983, no. 8.

26. Piris J.-C.: The Lisbon Treaty. A Legal and Political Analysis, CUP, Cambridge 2010.

27. Teubner G., Juridification. Concepts, Aspects, Limits, Solutions [in:] G. Teubner (ed.), 'Juridification of Social Spheres: A Comparative Analysis in the Areas of labour, corporate, antitrust, and social welfare law', Berlin-New York; 1987 EUI; series A, Law - 6003B.

28. Vesterdorf B., The Community Court System Ten Years from Now and Beyond: Challenges and Possibilities, 'European Law Review' 2003, vol. 28.

29. Weiler J.H.H.: The Constitution of Europe, CUP, Cambridge 1999.

30. Weiler J.H.H. (ed.), The EU, the WTO and the NAFTA: Towards a Common Law of International Trade?, OUP, Oxford 2001.

31. de Wilde P., No Polity for Old Politics? A Framework for Analyzing Politicization of European Integration, 'Journal of European Integration' 2011, no. 5.

32. de Wilde P., Zürn M., Can the Politicization of European Integration be Reversed, 'Journal of Common Market Studies' 2012, vol. 50.

33. Wouters J., Nollkaemper A., de Wet E. (eds), The Europeanisation of International Law: the Status of International Law in the EU and its Member States, TMC Asser Pres, The Hague 2008. 